\title{
RECEIVED
}

ORNLTM-13107
JAN 254996
OSTI

OAK RIDGE

NATIONAL

LABORATORY

MARTIN MARUETRA

\section{Nuclear Medicine Program Progress Report for Quarter Ending September 30, 1995}

\author{
F. F. Knapp, Jr. \\ K. R. Ambrose \\ A. L. Beets \\ H. Luo \\ D. W. McPherson \\ S. Mirzadeh
}


This report has ben reproduced directly from the best available copy.

Available to DOE and DOE contractors from the Office of Scientific and Technical Information, P.O. Box 62, Oak Ridge, TN 37831; prices available from (615) 576-8401, FTS 626-8401.

Available to the public from the National Technical Information Service, U.S. Department of Commerce, 5285 Port Royal Rd., Springfield, VA 22161.

This report was prepared as an account of work spensored by an agency of the United States Government. Neither the United States Government nor any agency thereof, nor any of their employees, makes any warranty, express or implied, or assumes any legal liability or responsibility for the accuracy, completeness, or usefulness of any information, apparatus, product, or process disclosed, or represents that its use would not infringe privately owned rights. Reference herein to any specitic commercial product, process, or service by trade name, trademark, manufacturer, or otherwise, does not necessarily consttute or imply its endorsement, recommendation, or favoring by the United States Government or any agency thereof. The views and opinions of authors expressed herein do not necessarily state or reflect those of the United States Government or any agency thereof. 


\section{DISCLAIMER}

ํㅗㄹ

This report was prepared as an account of work sponsored by an agency of the United States Government. Neither the United States Government nor any agency thereof, nor any of their employees, makes any warranty, express or implied, or assumes any legal liability or responsibility for the accuracy, completeness, or usefulness of any information, apparatus, product, or process disclosed, or represents that its use would not infringe privately owned rights. Reference herein to any specific commercial product, process, or service by trade name, trademark, manufacturer, or otherwise does not necessarily constitute or imply its endorsement, recommendation, or favoring by the United States Government or any agency thereof. The views and opinions of authors expressed herein do not necessarily state or reflect those of the United States Government or any agency thereof.

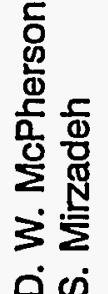

市

$\frac{0}{\frac{2}{8}}$

4

น
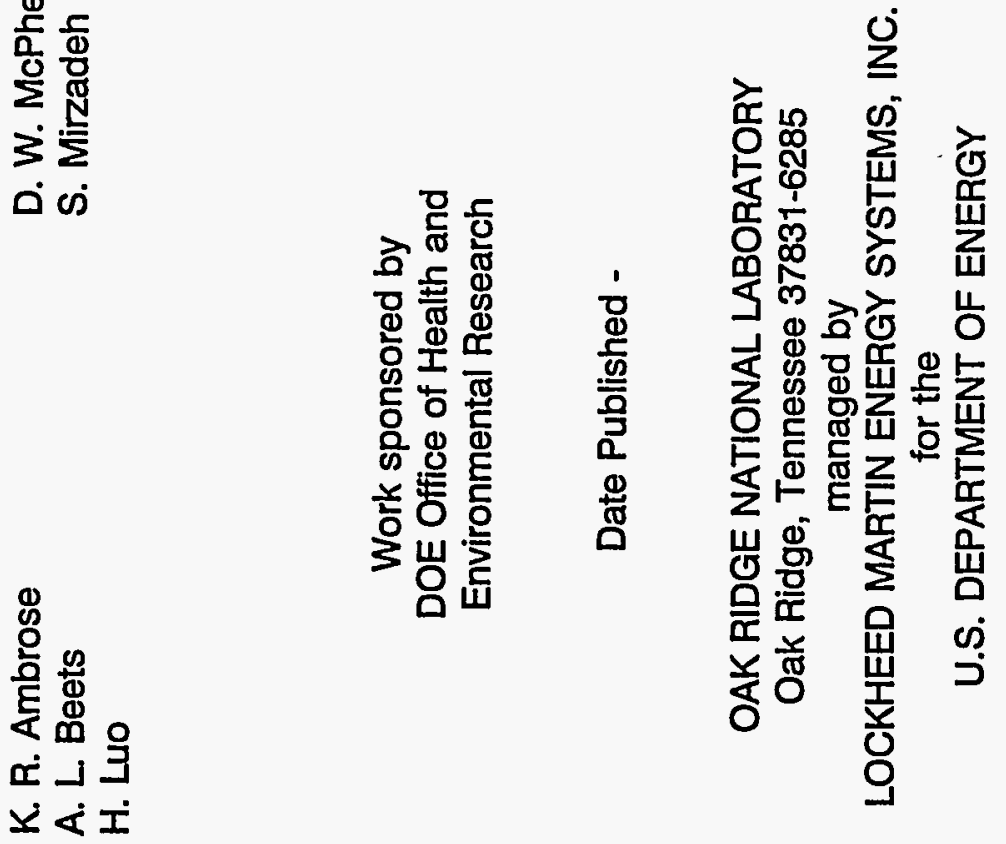

我 
Previous reports in this series:

ORNL/TM-5809

ORNL/TM-10294

ORNL/TM-5936

ORNLITM-10377

ORNL/TM-6044

ORNL/TM-10441

ORNL/TM-6181

ORNL/TM-6371

ORNL/TM-10618

ORNL/TM-6410

ORNL/TM-10711

ORNL/TM-6638

ORNL/TM-10839

ORNL/TM-6639

ORNLTM-11014

ORNL/TM-6771

ORNLTM-11043

ORNL/TM-6916

ORNLTM-11145

ORNL/TM-11224

ORNL/TM-11304

ORNL/TM-6958

ORNLTM-11377

ORNL/TM-11427

ORNL/TM-7223

ORNL/TM-11550

ORNL/TM-7411

ORNL/TM-11570

ORNL/TM-7482

ORNL/TM-11721

ORNLTM-7685

ORNL/TM-11755

ORNLTM-7775

ORNL/TM-11830

ORNL/TM-11881

ORNL/TM-11992

ORNL/TM-8123

ORNL/TM-12054

ORNL/TM-8186

ORNL/TM-12110

ORNL/TM-8363

ORNL/TM-12159

ORNL/TM-12222

ORNL/TM-8533

ORNL/TM-12312

ORNL/TM-12343

ORNL/TM-12411

ORNL/TM-12485

ORNL/TM-12661

ORNL/TM-12707

ORNL/TM-12789

ORNL/TM-12875

ORNL/TM-12909

ORNL/TM-12965

ORNL/TM-13053

ORNL/TM-9707

ORNL/TM-9784

ORNL/TM-9937

ORNL/TM-10082

ORNLITM-10238 
- 


\section{CONTENTS}

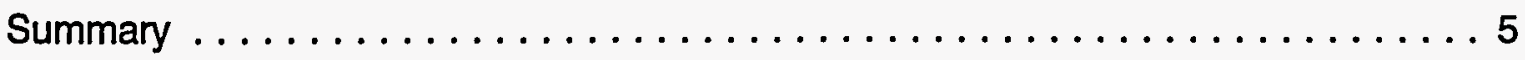

Evaluation of the Production of Lutetium-177 in the Oak Ridge

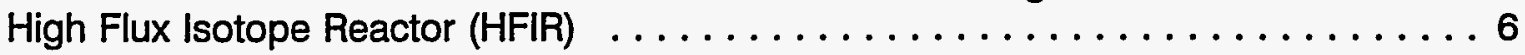

Summary of HFIR Irradiations for the Period Ending September 30, $1995 \ldots \ldots \ldots$.

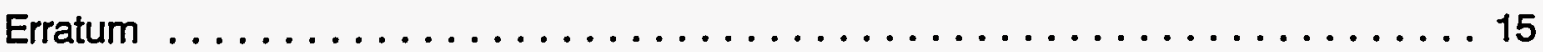

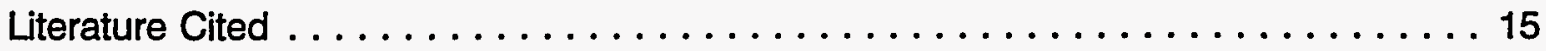

Other Nuclear Medicine Group Activities $\ldots \ldots \ldots \ldots \ldots \ldots \ldots \ldots \ldots \ldots$

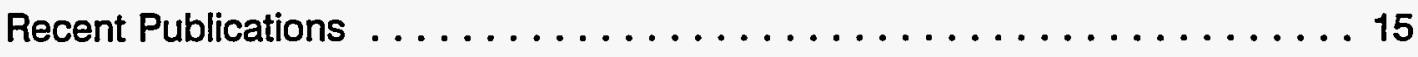

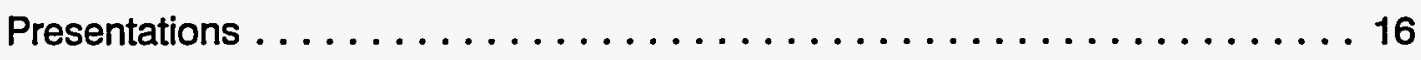

Medical Cooperative Shipments $\ldots \ldots \ldots \ldots \ldots \ldots \ldots \ldots \ldots \ldots \ldots 18$

Visitors and Guest Assignments $\ldots \ldots \ldots \ldots \ldots \ldots \ldots \ldots \ldots \ldots \ldots$ 



\section{SUMMARY}

In this report, we describe the results for study of the production of lutetium-177 $\left({ }^{177_{L u}}\right)$ in the High Flux Isotope Reactor (HFIR). Two pathways for production of ${ }^{177}$ Lu were studied which involved both direct neutron capture on enriched ${ }^{176} \mathrm{Lu},{ }^{176} \mathrm{Lu}(\mathrm{n}, \gamma)^{177} \mathrm{Lu}$, reaction and by decay of ytterbium-177 ( $\left.{ }^{177} \mathrm{Yb}\right)$ produced by the ${ }^{176} \mathrm{Yb}(\mathrm{n}, \gamma)^{177} \mathrm{Yb}\left(\beta^{-} \rightarrow\right)$ reaction. Although the direct route is more straight forward and does not involve any separation steps, the indirect method via $\beta$-decay of ${ }^{177} \mathrm{Yb}$ has the advantage of providing carrier-free ${ }^{177} \mathrm{Lu}$, which would be required for antibody radiolabeling and other applications where very high specific activity is required..

Substrates required for preparation of tissue-specific agents and several radioisotopes were also provided during this period through several Medical Cooperative Programs. These include the substrate for preparation of the "BMIPP" cardiac imaging wihich was developed in the ORNL Nuclear Medicine Program, which was provided to Dr. A. Giodarno, M.D. and colleagues at the Catholic University Hospital in Rome, Italy. Tungsten-188 produced in the ORNL HFIR was also provided to the Catholic University Hospital for fabrication of a tungsten-188/rhenium-188 generator to provide carrier-free rhenium-188 which will be used for preparation of rhenium-188labeled methylenediphosphonate (MDP) for initial clinical evaluation for palliative treatment of bone pain (L. Troncone, M.D.). Samples of substrates for preparation of the new ORNL "IQNP" agent for imaging of muscarinic-cholinergic receptors were provided to the Karolinska Institute in Stockholm, Sweden, for preparation of radioiodinated IQNP for initial imaging studies with this new agent in monkeys and for tissue binding studies with human brain samples obtained from autopsy (C. Halldin, Ph.D.). 


\section{Evaluation of the Production of Lutetium-177 in the Oak Ridge High Flux Isotope Reactor (HFIR)}

Lutetium-177g ( $\left.{ }^{177 g} \mathrm{Lu}\right)$ can be utilized for radiotherapeutic applications when chelated to tumorassociated antibodies for radioimmunotherapy. It has also been proposed as radioisotope source in bracheytherapy. Lutetium-177g decays with a half-life of $6.7 \mathrm{~d}$ to the ground state of stable hafnium-177 ( ${ }^{\left.177_{\mathrm{H}}\right)} 78 \%$ of the time $\left(E_{B 1}{ }^{\max }=0.497 \mathrm{MeV}\right)$, to the first excited state $9.7 \%$ of the time $\left(E_{B 2} \max =0.384 \mathrm{MeV}\right)$, and to the $0.321 \mathrm{MeV}$ level $12 \%$ of the time $\left(E_{B 3}{ }^{\max }=0.176\right.$

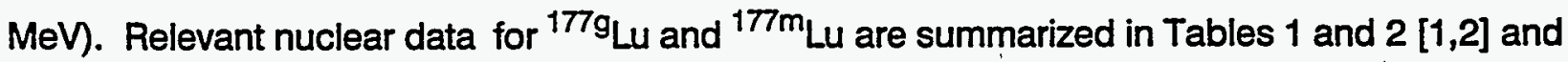
a simplified decay scheme for ${ }^{1779} \mathrm{Lu}$ is shown in Figure 1 . As seen de-excitation from the first exited state level $(0.1129 \mathrm{MeV})$ provides a $\gamma$-ray for imaging which has an energy of $113 \mathrm{keV}$ and an intensity of $6.6 \%$. About $12 \%$ of this transition converts at the electronic shell of the $\mathrm{HF}$ providing low range secondary electrons and $X$-rays (Table 2). The de-excitation from the 0.321 $\mathrm{MeV}$ level to the first exited state level provides a $\gamma$-ray at $208 \mathrm{keV}(12 \%)$ which may be suitable for deep-organ imaging. The average $B^{-}$energy of ${ }^{1779} \mathrm{Lu}$ is $0.133 \mathrm{MeV}$ and the average equilibrium dose rate constant for ${ }^{177 g} \mathrm{Lu}$ is estimated to be $\sim 0.5 \mathrm{~g}-\mathrm{rad} / \mu \mathrm{Ci}-\mathrm{h}$, which is similar to that for ${ }^{67} \mathrm{Cu}$ (Table 1) [3].

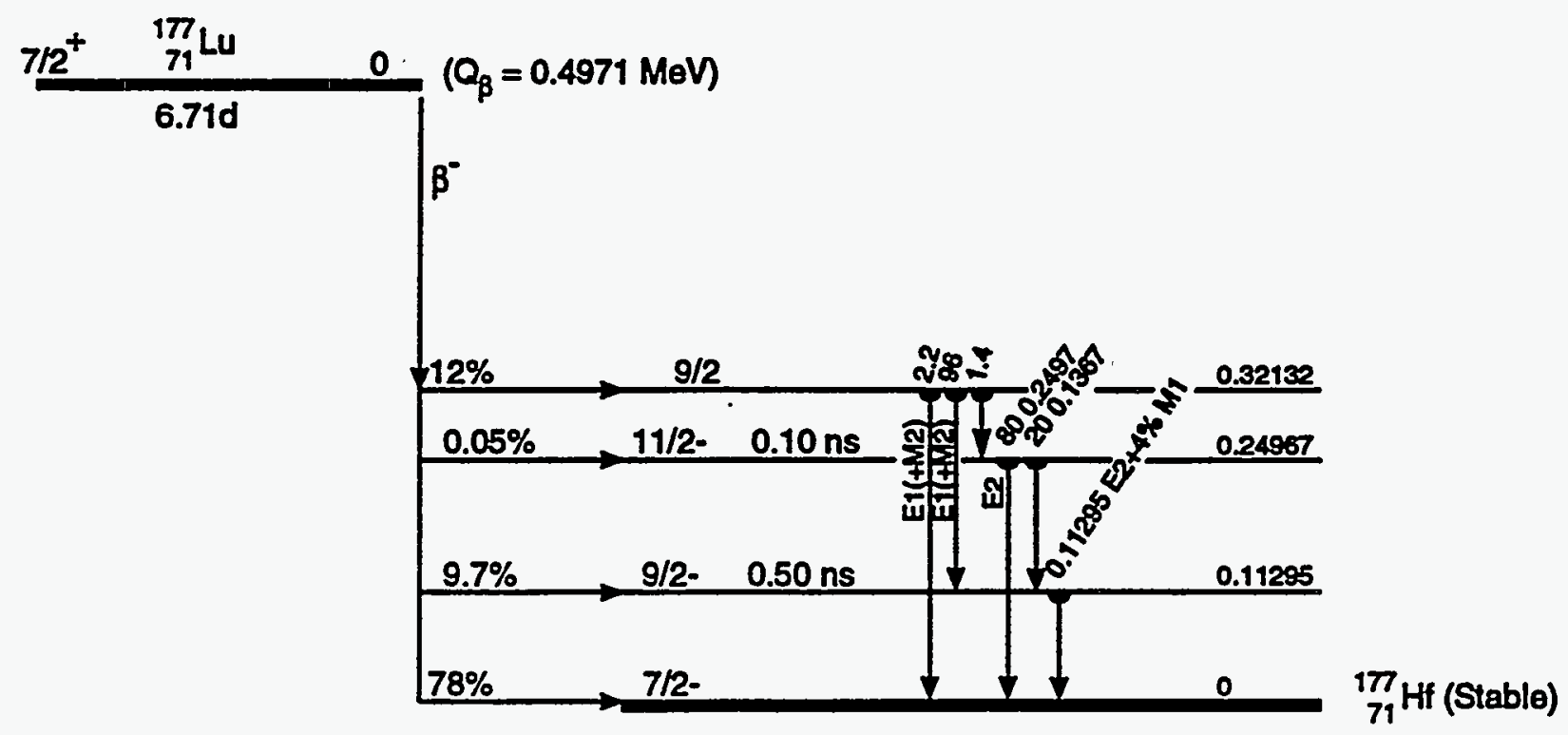

Figure 1. A simplified decay scheme of ${ }^{177 g_{L u}}$ 
Table 1. Nuclear data for ${ }^{1779}$ Lu and ${ }^{177 m_{L u}}$

\begin{tabular}{|c|c|c|c|c|c|c|c|c|}
\hline \multirow{3}{*}{$\begin{array}{l}\text { Radio- } \\
\text { nuclide }\end{array}$} & \multirow[b]{3}{*}{$t_{1 / 2}$} & \multirow{3}{*}{$\begin{array}{l}E_{\beta}^{a v} \\
(\mathrm{keV})\end{array}$} & \multirow{3}{*}{$\begin{array}{l}\mathrm{E}_{\gamma}\left(\mathrm{I}_{\gamma}\right) \\
(\mathrm{keV})(\%)\end{array}$} & \multirow{3}{*}{$\begin{array}{l}\text { Mode of } \\
\text { Production }\end{array}$} & \multicolumn{4}{|c|}{ Reaction Cross-sections ${ }^{a}$} \\
\hline & & & & & \multicolumn{2}{|c|}{ Production } & \multicolumn{2}{|c|}{ Burn-up } \\
\hline & & & & & Th. & $\mathrm{I}_{0}$ & Th. & $I_{0}$ \\
\hline \multirow[t]{3}{*}{${ }^{1779} \mathrm{Lu}$} & $6.71 d$ & 133 & $113(6.6)$ & ${ }^{176} \operatorname{Lu}[\mathrm{n}, \gamma]$ & 2090 & 1087 & 200 & 400 \\
\hline & & & $208(11)$ & ${ }^{176} \mathrm{Yb}[\mathrm{n}, \gamma]^{177} \mathrm{Yb}\left(B^{-}, 1.9 \mathrm{~h}\right)$ & 2.85 & 6.3 & & \\
\hline & & & many low & & & & & \\
\hline \multirow[t]{4}{*}{$177 m_{L u}$} & $160 \mathrm{~d}$ & IT (22\%) & $113(21.5)$ & ${ }^{176} L u[n, \gamma]$ & 2.8 & 4.7 & 100 & 200 \\
\hline & & $B^{-}(78 \%)$ & $208(61.2)$ & & & & & \\
\hline & & $<\beta^{-}>32$ & $228(36.6)$ & & & & & \\
\hline & & & $379(29.9)$ & & & & & \\
\hline
\end{tabular}

${ }^{\mathrm{a}} \mathrm{Th}=$ thermal, $\mathrm{I}_{0}=$ resonace integral 
Table 2. Gamma-rays, KX-rays and K \& L Converted Electrons in the Decay of ${ }^{177 g}$ Lu $^{a}$

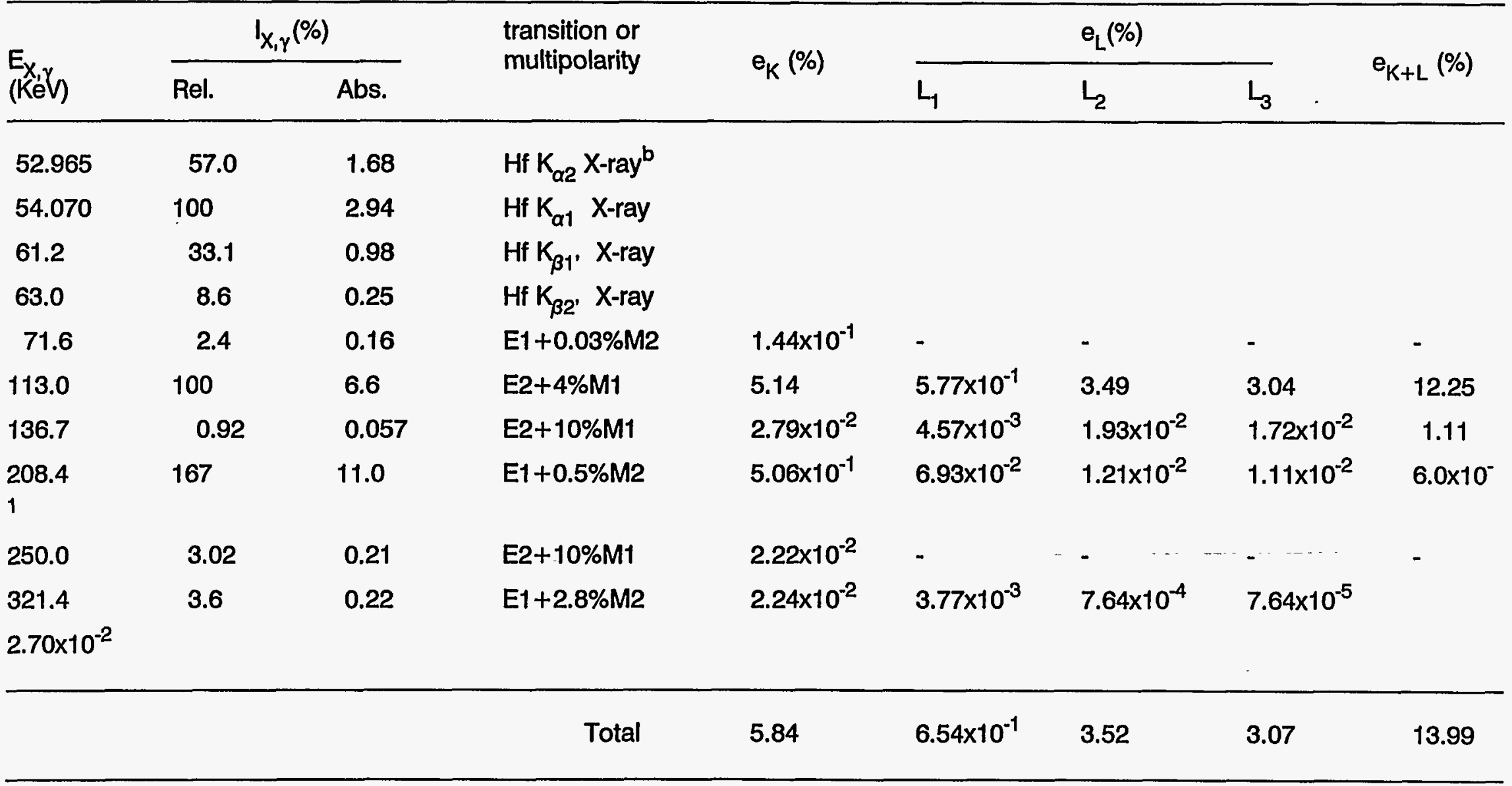

a) Ref. 1,2, ${ }^{\text {b) }}$ For description of the notation see Ref. 1, Appendix 12. 
Because of the rather longer half-life, ${ }^{177 g} \mathrm{Lu}$ is most suited for the radiolabeling of antibodies which have slow targeting kinetics, and a lower equilibrium dose rate constant makes ${ }^{1779} \mathrm{Lu}$ useful for radiotherapy of soft tissues. In addition, ${ }^{1779} \mathrm{~L}$ has chemical characteristics suitable for protein labelling with bifunctional chelating agents such as the eight coordinate DTPA, other DTPA derivatives or DOTA. Lutetium is the heaviest member of the lanthenides but has an ionic radius comparable to $\mathrm{Y}^{3+}$ as the result of the lanthenide contraction." In coordination number 6 , the ionic radius of $\mathrm{Lu}^{3+}$ is $89.1 \mathrm{pm}$, which is about $4 \mathrm{pm}$ smaller than that of $\mathrm{Y}^{+3}$. At $25^{\circ} \mathrm{C}$ and $0.1 \underline{M}$ ionic strength, the equilibrium constant of the $L^{3+}$-DTPA complex (ML/M.L) is $2.51 \times 10^{22} \mathrm{M}^{-1}$, in comparison with $1.12 \times 10^{22} \mathrm{M}^{-1}$ for the Y-DTPA complex [4].

Due to a rather large cross-section $\left(\sigma_{\text {th }}=2090 \mathrm{~b}, \mathrm{l}_{0}=1087 \mathrm{~b}\right.$ ), high specific activity ${ }^{1779} \mathrm{Lu}$ can be obtained directly by the ${ }^{1769} L u[n, \gamma]{ }^{17 / L u}$ reaction (see Figure 2 ). The natural abundance of ${ }^{176} \mathrm{Lu}$ is only $2.6 \%$, however, and the highest enrichment available from the ORNL isotopes Distribution Office (IDO) is $72 \%$ at a cost of $\$ 220.95 / \mathrm{mg}$. Alternatively, ${ }^{177 \mathrm{~g}} \mathrm{Lu}$ can be obtained indirectly from $B^{-}$decay of ${ }^{177} Y b\left(t_{1 / 2}=1.9 h, E_{B}{ }^{\max }=400 \mathrm{keV}\right)$, as described earlier.

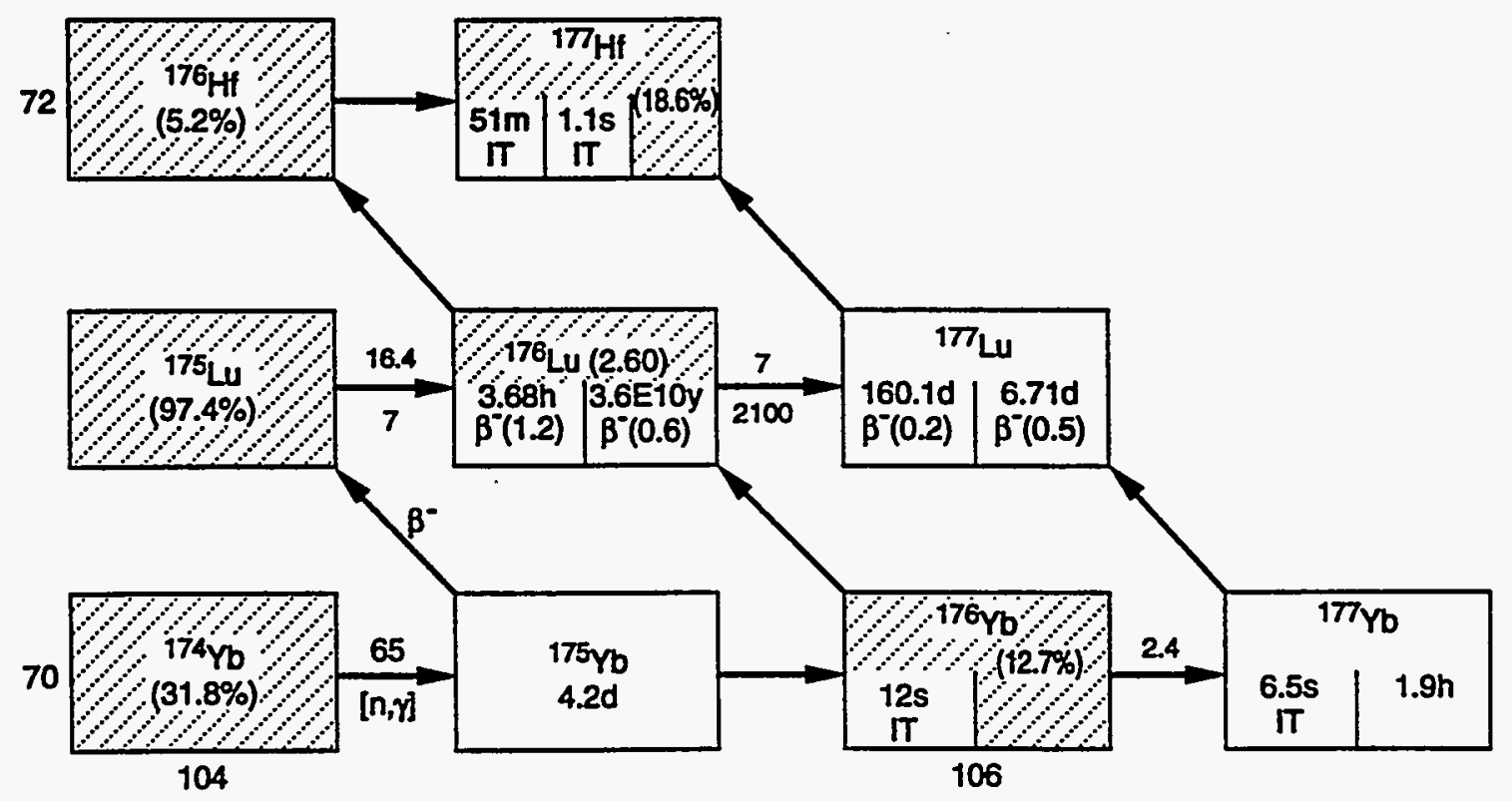

Figure 2. Scheme for Production of ${ }^{177 g_{\mathrm{Lu}}}$ 
In this case, the ${ }^{177} \mathrm{Yb}$ parent nuclei is produced in a fission nuclear reactor with neutron capture on ${ }^{176} \mathrm{Yb}$ which has a natural abundance of $12.7 \%$. Ytterbium-176 enriched to $97.79 \%$ is also available from the IDO at a cost of $\$ 17.40 / \mathrm{mg}$. Obviously, the indirect route yielding carrier-free $177 \mathrm{~g}_{\mathrm{Lu}}$ is the desired production route if $\mathrm{Lu}$ can be separated efficiently from the $\mathrm{Yb}$ target material. We have recently reported similar separation of carrier-free holmium-166 $\left({ }^{166} \mathrm{Ho}\right)$ from milligram quantities of dysprosium (Dy). In certain applications, such as protein labelling, the use of a high specific activity radioisotopes is often essential. In addition, the indirect route produces ${ }^{177} \mathrm{Lu}$ which is free from the $160-\mathrm{d}{ }^{177 \mathrm{~m}} \mathrm{Lu}$. This radioisotope is unavoidably coproduced with ${ }^{177} \mathrm{Lu}$ by the ${ }^{176} \mathrm{Lu}[\mathrm{n}, \gamma]^{177 \mathrm{~m}_{\mathrm{Lu}} \text { reaction. }}$

For a one-hour irradiation of two natural $\mathrm{Lu}$ targets (as $\mathrm{Lu}_{2} \mathrm{O}_{3}$, see Table 3 for composition) in position \#4 of the HFIR, the experimental yield of ${ }^{177} \mathrm{Lu}$ is $(2.44 \pm 0.20) \times 10^{3} \mathrm{MBq} / \mathrm{mg}$ of $\mathrm{Lu}$, corresponding to a value of $(9.42 \pm 0.99) \times 10^{4} \mathrm{MBq} / \mathrm{mg}$ of ${ }^{176} \mathrm{Lu}$. The ratio of the ${ }^{177 \mathrm{~m}} \mathrm{Lu} /{ }^{177 g} \mathrm{Lu}$ in this case is $4.8 \times 10^{-3} \%$. Under similar conditions, the yields from two $43 \%$ enriched ${ }^{176} \mathrm{Lu}$ targets were $(4.18 \pm 0.59) \times 10^{4} \mathrm{MBq} / \mathrm{mg}$ of $\mathrm{Lu}$ and $(9.46 \pm 1.29) \times 10^{4} \mathrm{MBq} / \mathrm{mg}$ of ${ }^{176} \mathrm{Lu}$ with a $177 \mathrm{mLu} / 17 \mathrm{~g} \mathrm{Lu}$ ratio of $4.6 \times 10^{-3} \%$. The averaged yield from natural and $43 \%$ enriched target was (9.44 \pm 0.78$) \times 10^{4} \mathrm{MBq} / \mathrm{mg}$ of ${ }^{176} \mathrm{Lu}$ in comparison to the theoretical yield of $5.69 \times 10^{4} \mathrm{MBq} / \mathrm{mg}$ of ${ }^{176} \mathrm{Lu}$ for a $\mathrm{Y}_{\text {Exp. }} Y_{\text {Theo. }}$ of 1.66. The theoretical yield of ${ }^{177 g} \mathrm{Lu}$ as a function of the irradiation time is shown in Figure 3. From these data it is clear that saturation will be reached within 4 days in $\mathrm{HT \# 4}$ or \#6 with an expected yield of $\sim 3 \times 10^{6} \mathrm{MBq}\left(\sim 80 \mathrm{Ci}\right.$ ) per $\mathrm{mg}$ of ${ }^{166} \mathrm{Lu}$. Since the ${ }^{177 \mathrm{~m} L u} /{ }^{177 \mathrm{~g}} \mathrm{Lu}$ ratio will increase with the irradiation time (Figure 4), for a 4-d irradiation the fraction of $177 \mathrm{~m} \mathrm{Lu}$ at the end of irradiation (EOI) is expected to be less than $0.01 \%$ for a $4-d$ irradiation period. 


\section{1}

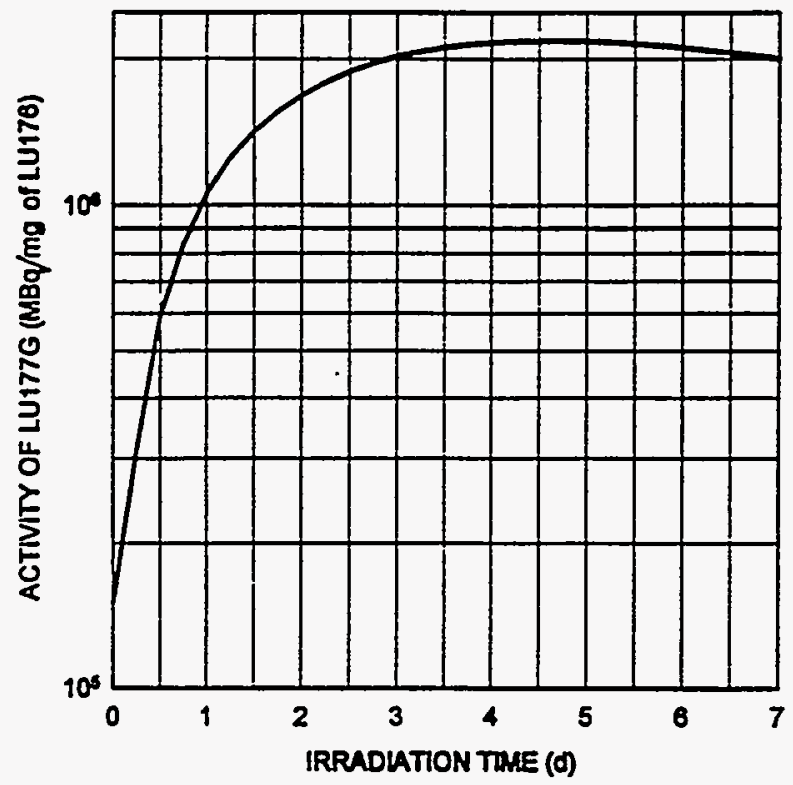

Figure 3. Direct production of ${ }^{1779} \mathrm{Lu}$ - theorerical yield of ${ }^{1779} \mathrm{~g} \mathrm{Lu}$ as a function of the irradiation time. HT\#4 or $6, \phi_{\text {th }}=1.76 \times 10^{15}$, n.s. ${ }^{-1} . \mathrm{cm}^{-2}$, th/epi=26.

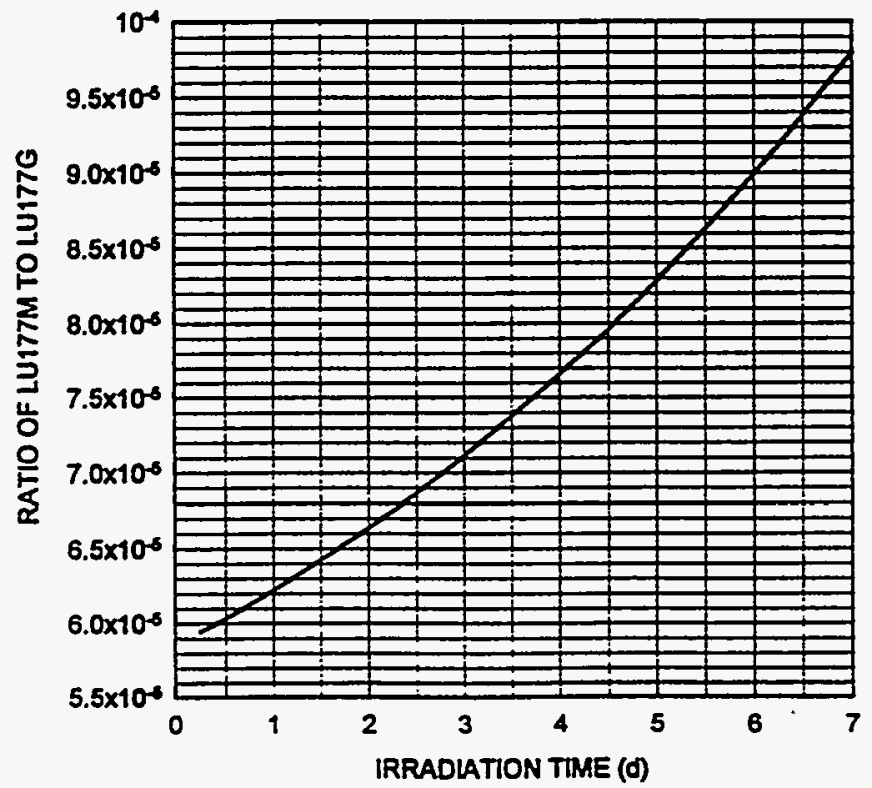

Figure 4. The ratio of ${ }^{177 m_{\mathrm{Lu}}}$ to ${ }^{177} \mathrm{~g}_{\mathrm{Lu}}$ as a function of irradiation time at the HT\#4 or 6. $\phi_{\text {th }}=1.76 \times 10^{15}$, n.s..$^{-1} \cdot \mathrm{cm}^{-2}$, th/epi $=26$. 
As indicated in Table 3, the yield from the indirect route (from decay of $\left.{ }^{177} \mathrm{Yb}\right)$ is $(7.46 \pm 0.50) \times 10^{1}$ $\mathrm{MBq} / \mathrm{mg}$ of ${ }^{176} \mathrm{Yb}\left(2.0 \mathrm{mCi} / \mathrm{mg}\right.$ of $\left.{ }^{176} \mathrm{Yb}\right)$ for a $1 \mathrm{~h}$ irradiation in $\mathrm{HT \# 5}$. This experimental yield is $\sim 20 \%$ lower than the theoretical value using calculations which allow for a 12-h decay period post irradiation. The activity of ${ }^{177 \mathrm{~g}} \mathrm{Lu}$ in the irridated $\mathrm{Yb}$ target decayed by a factor of more than thousand fold with a half life of $6.7 \mathrm{~d}$, results in an estimated value for the ${ }^{177 \mathrm{~m}} \mathrm{Lu} /{ }^{177 \mathrm{~g}} \mathrm{Lu}$ ratio of $\leq(1.0 \pm 0.5) \times 10^{-4} \%$. The theoretical yields of both ${ }^{177} \mathrm{Yb}$ and ${ }^{177 \mathrm{~g}} \mathrm{Lu}$ as a function of time are shown in Figure 5 . In this case, the yield of ${ }^{177 g} \mathrm{Lu}$ will reach a saturation value of $\sim 1.5 \times 10^{4}$ $\mathrm{MBq}(411 \mathrm{mCi}) / \mathrm{mg}$ of ${ }^{176} \mathrm{Yb}$ within 21 days of irradiation in HT\#5. A 3D graph showing the theoretical yields of ${ }^{177 g} \mathrm{Lu}$ as a function of the irradiation time and total time (sum of the irradiation time and post-EOI decay period) is depicted in Figure 6. As seen, the post-EOI contribution from the decay of ${ }^{177} \mathrm{Yb}$ to the total activity of ${ }^{1779} \mathrm{Lu}$ decrease rapidly as a function of irradiation time. As shown in Figure 7 , this contribution becomes negligible $(<1 \%)$ for irradiation time of more than 20 hours. Although the yield of the indirect route is lower than the direct route by a factor of 1000 , the specific activity of ${ }^{177} \mathrm{Lu}$ from both routes will be almost the same assuming carrier-free $L u$ can be separated from $Y b$ in 1 part per thousand. Studies are currently in progress to evaluate various ion exchange methods for the spearation of carrier-free ${ }^{177}$ Lu from carrier ${ }^{176} \mathrm{Yb}$. 
Table 3. Summary of HFIR Production of ${ }^{177 g_{L u}}$

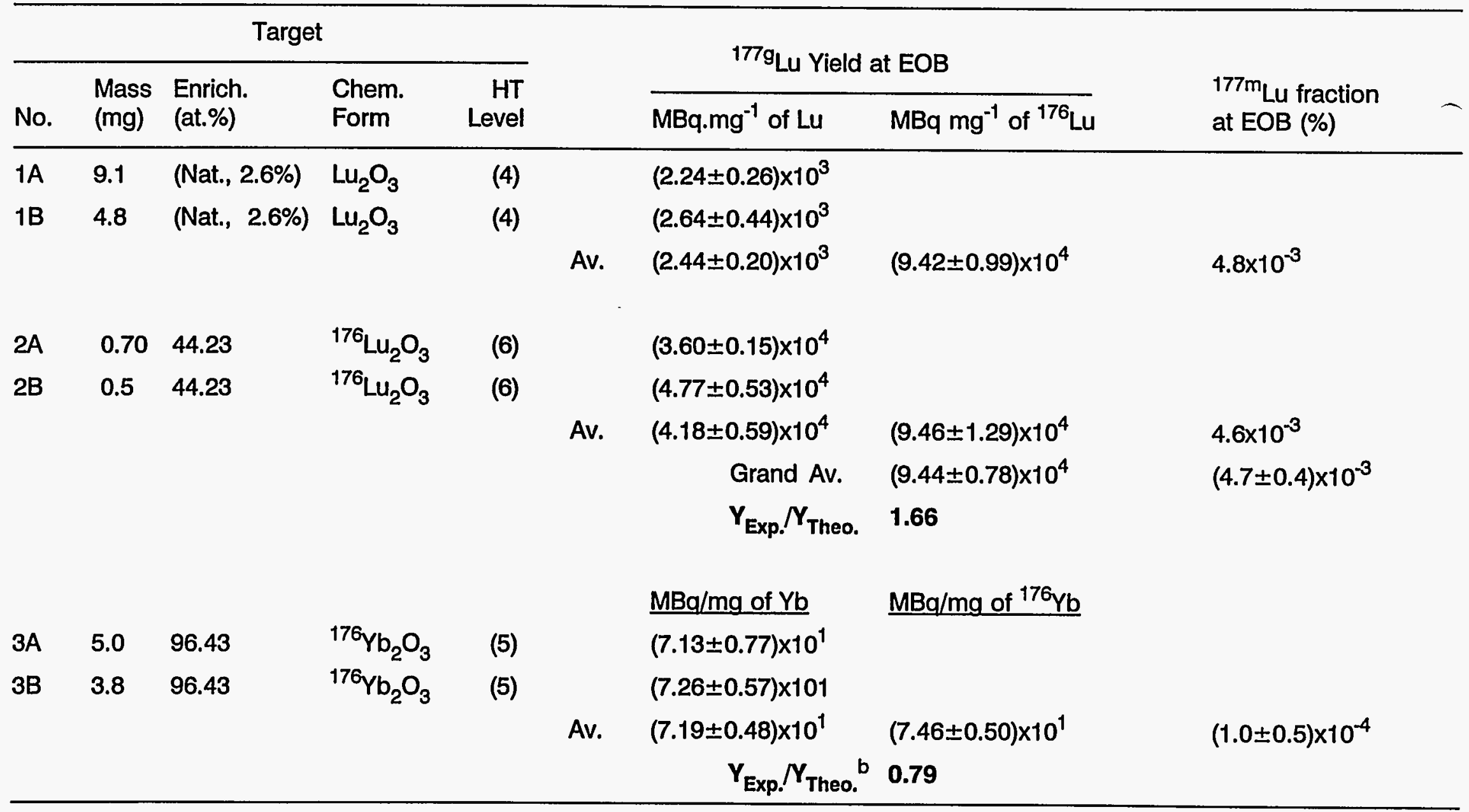

${ }^{a}$ Reactor power level $=85 \mathrm{MWt}$, Irradiation time $=1 \mathrm{~h} .{ }^{\mathrm{b}}$ Allowed a 12-h post EOB decay 


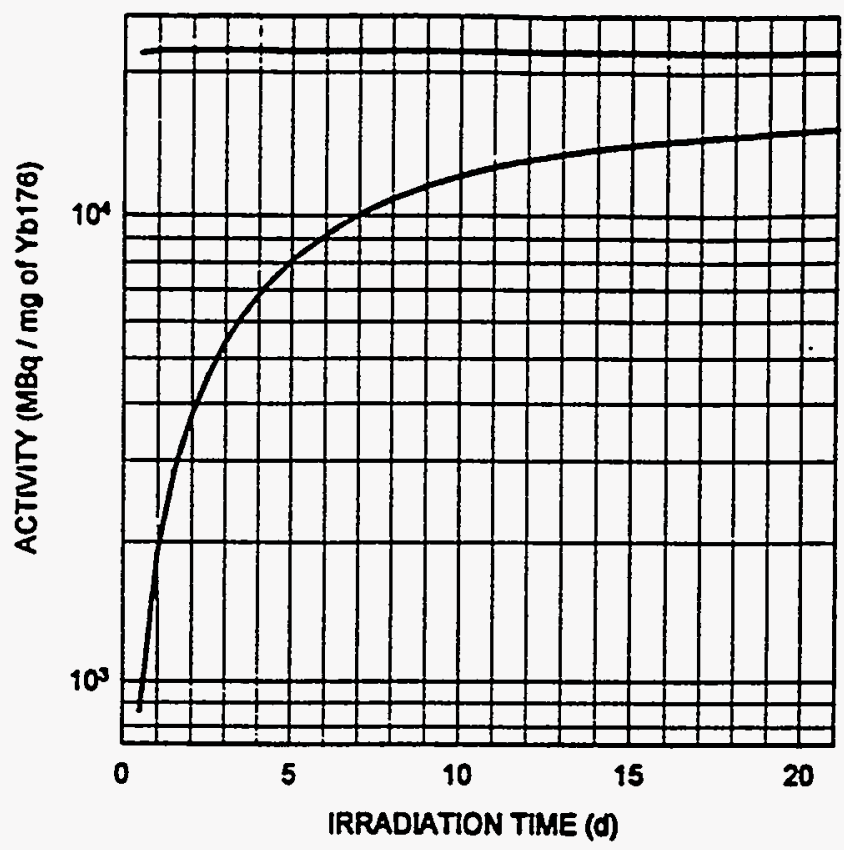

YB177!

LU177C

Figure 5. Indirect production of ${ }^{177 \mathrm{~g}} \mathrm{Lu}$ - theroretical yields of ${ }^{177} \mathrm{Yb}$ and ${ }^{1779} \mathrm{Lu}$ as a function of irradiation time. HR\#5, $\phi_{\text {th }}=2.05 \times 10^{15}, \mathrm{n} . \mathrm{s}^{-1} \cdot \mathrm{cm}^{-2}$, th/epi=20.

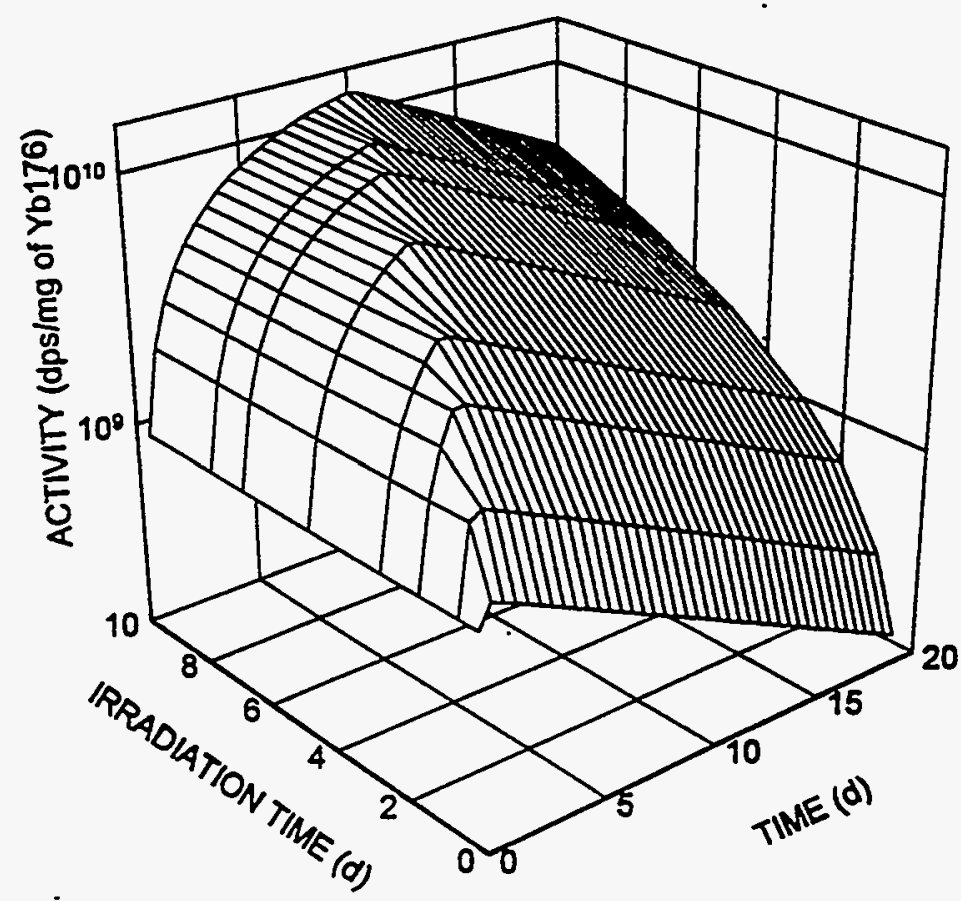

Figure 6. Indirect production of ${ }^{177 g} \mathrm{Lu}$ - a $3 \mathrm{D}$ graph of the theoretical yield of ${ }^{177 \mathrm{~g}} \mathrm{Lu}$ as a function of the irradiation time and total time. 


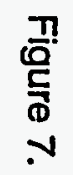

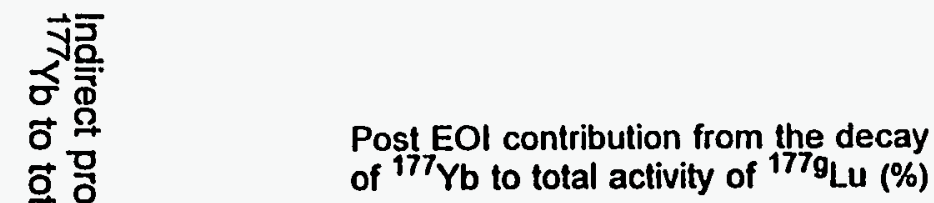

of ${ }^{177} \mathrm{Yb}$ to total activity of $177 g_{L} u(\%)$

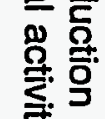

突号

옥

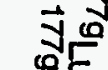

$E$

今

め)

㤩

홍

옹

完

章.

ญ

음을

宁 菑

实员
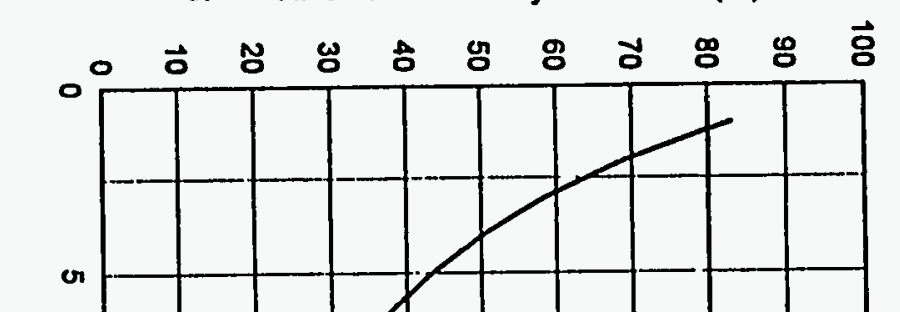

ज

竞

承

vi

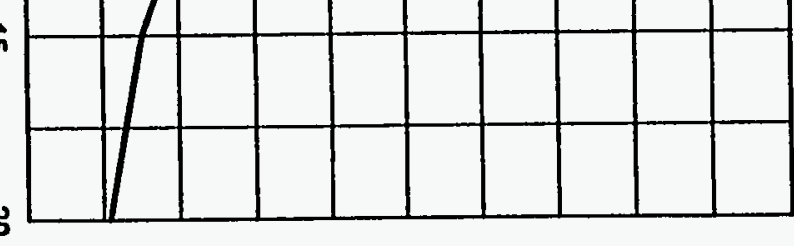

욱 


\section{Literature Cited}

1. Lederer, C. M., and Shirley, V. S., Editors, Table of Isotopes, 7th Ed., John Wiley \& Sons Inc., New York 1978.

2. Reus, U. and Westmeier, W., Catalog of Gamma-rays from Radioactive Decay, At. Data and Nucl. Data Tables. Parts I and II, 29, 1983.

3. Weber, D. A., Eckerman, K. F., Dillman, L. T., Ryman, J. C., MIRD, Radionuclide Data and Decay Schemes, Society of Nuclear Medicine, New York (1988).

4. Martel, A. E. and Smith, R. M., Critical Stability Constants, Vol. 1, Amino Acids, Plenum Press, New York (1974), pp 281-285.

5. Dadachova, E., Mirzadeh, S., Lambrecht, R. M., Hetherington, E. and Knapp, Jr. F. F., "Separation of Carrier-free Holmium-166 from Neutron-irradiated Dysprosium Targets", Journal of Analytical Chemistry, 66, $4272-4277$ (1994) .

\section{Erratum}

The following corrections are for section in ORNL/TM-13053, published September 1995:

Page 7, Line 3. Phenylmagnesium bromide should be corrected to the original agent prepared from 1-bromo-5-chloropentane.

\section{Other Nuclear Medicine Group Activities}

\section{Publications}

Wang, S. J., Lin, W. Y., Hsieh, B. T., Shen, L H., Tsai, Z. T. and Knapp, F. F., Jr., "Rhenium188 Sulfur Colloid as a Radiation Synovectomy Agent," Eur. J. Nucl. Med., 22, 505-507 (1995).

Gilter, M. S., Boulay, S. F., Sood, V. K., McPherson, D. W., Knapp, F. F. (Russ) Jr., Zeeberg, B.R. and Reba, R. C. "Characterization of in vivo brain muscarinic acetylcholine receptor sybtype selectively by competition studies against (R,R)-[ $\left.{ }^{125} l\right]-1 Q N B, "$ Brain Research, 687, 71 78 (1995). 


\section{Presentations}

ORNL Nuclear Medicine Program Staff members D. W. McPherson and S. Mirzadeh participated in the recent International Symposium on Radiopharmaceutical Chemistry held in Vancouver, Canada, on August 13-17, 1995. The following papers were presented and co-authored by members of the ORNL Program:

E. Dadachova, S. V. Smith, N. DiBartolo, P. F. Schmidt, S. Mirzadeh and E. L. Hetherington, "Labeling of Proteins with ${ }^{166} \mathrm{Ho} . "$

E. Dadachova, S. V. Smith, P. F. Schmidt and S. Mirzadeh, "Electrochemical Reduction of ${ }^{188}$ Re for Protein Labeling."

D. W. McPherson, H. Luo, A. L. Beets, B. Zeeberg, V. Sood, R. C. McRee, R. C. Reba and F. F. Knapp, Jr. "Preparation, In Vitro and In Vivo Evaluation of New Fluoroalkyl QNB Analogues as Potential mAChR Ligands for PET Studies."

S. Mirzadeh, A. L. Beets and F. F. Knapp, Jr. "HFIR-Produced Radioisotopes of Current Medical Interest."

A. Schaffland, S. Guhlke, F. F. Knapp, Jr., P. O. Zamora and H. J. Biersack, "Preand Post-Conjugate Labeling of Amies and Peptides with ${ }^{188}$ Re Using the $\mathrm{MAG}_{3}$ Chelate."

V. Strijckmans, D. W. McPherson, F. F. Knapp, Jr., C. Loc'h and B. Maziere, "[ $\left.{ }^{76} \mathrm{Br}\right]-Z$ $(R, R)-,Q N P$ : A High Affinity PET Radiotractor for Central Muscarinic Receptors."

F. F. (Russ) Knapp, Jr. attended the European Association of Nuclear Medicine (EANM) Congress held in Brussels, Belgium, on August 26-30, 1995. In addition to participating in this meeting and assisting the staff of the Department of Energy Isotope Production and Distribution Program (IPDP), he also met as an editorial board member with the Editorial Board of the European Journal of Nuclear Medicine. Members of the ORNL Program co-authored the following papers at the EANM Congress: 
Grillenberger, K., McPherson, D., Hartung, T., Knapp, Jr., F. F. and Reske, S.N. "An Improved Method for Labeling MAB with Carrier-Free Rhenium-188."

Hosono, M., Hosono, M, Haberberger, T., Zamora, P., Guhlke, S., Bender, J., Knapp, Jr. F. F. and Biersack, H.-J. "Targeting of Small-Cell Lung Cancer by Octreotide Labeled With 1-125, In-111, and Re-188 in a Mouse Model."

Lin, W., Chen, M., Wang, S., Hseih, B., Tsai, Z, Ting, G. and Knapp, Jr., F: F. "Biodistribution of Rhenium-188 Lipiodol in Rats Following Hepatic Arterial Injection."

Sloof, G., Visser, F. C., Comans, E. and Knapp, Jr. F. F. "Correlation of Heterogeneous Blood Flow and Uptake of a DiMethyl-Branched lodo Fatty Acid in the Normal and Ischemic Dog Heart."

Wang, S., Chen, M., Lin, W., Hseih, B, Tsai, Z, Ting, G, and Knapp, Jr. F. F. "Rhenium-188 Labeling of Lipiodol for Hepatoma Therapy."

Wang, S., Lin, W., Hseih, B, Tsai, Z, Ting, G. and Knapp, Jr. F. F. "Studies on Re188 Sulfur Colloid for Use as a Radiation Synovectomy Agent."

\section{Medical Cooperative Shipments}

During this period several radioisotopes were provided to collaborators for ongoing research projects through our Medical Cooperative Programs which included tungsten-18 which was provided to Sorin Biomedica in Milan, Italy for fabrication of a sterile tungsten-188/rhenium-188 generator under GMP's to obtain rhenium-188 for preparation of rhenium-188-MDP for initial clinical evaluation of rhenium-188-MDP for bone palliation studies at the Catholic University Hospital in Rome, Italy (L. Troncone, M.D.). Tungsten-188/rhenium-188 generators were also provided to RhoMed, Inc. through a CRADA arrangement for radiolabeling of peptides and somatostatin analogues for tumor therapy (B. Rhodes, Ph.D. and P. Zamora, Ph.D., et al.) . Tungsten-188 ( $1 \mathrm{Ci}$ ) was provied to Nordion, Inc. through the UPDP. Scandium-47 and tin-117m which were supplied to the Medical Department at the Brookhaven National Laboratory ( $L$. Mausner, Ph.D. and S. C. Srivsatava, Ph.D.). The scandium-47 is being used for antibody labeling for animal studies and the tin- $117 \mathrm{~m}$ is used in Phase II patient studies for evaluation of bone palliation with tin-117m-DTPA complex in a CRADA with Diatech, Inc. 
Visitors and Guest Asssignment

During the July 1-September 30, 1995, several guests who joined the Nuclear Medicine Program included Florian Mokler, a medical student from the University of Mainz, Germany, who will work at ORNL for the September 1995-February 1996 period to evaluate the metabolism of new cardiac imaging agents. Several visitors during this period included:

July 25, 1995, George B. Crawford, Scintillation Technologies, Knoxville, TN July 25, 1995 Prof. Nicholas Schad, Passau, Germany August 17, 1995, Prof. E. S. El'Ashray (Medical Chemistry) Alexandria, Egypt 


\section{ORNL/TM-13107}

\section{INTERNAL DISTRIBUTION}

1. C. W. Alexander

2. K. R. Ambrose

3. A. L. Beets

4. B. A. Berven

5. E. D. Collins

6. K. F. Eckerman

7-11. F. F. Knapp, Jr

12. H. Luo

13. D. W. McPherson

14. S. Mirzadeh
15. B. Patton

16. D. E. Reichle

17. P. S. Rohwer

18. R. E. Swaja

19. S. J. Wolfe

20-22. Central Research Library

23. Document Record Section

24-26. Laboratory Records Dept

27. Lab Records, ORNL - RC

28. ORNL Patent Section

\section{EXTERNAL DISTRIBUTION}

29. H. L. Atkins, M.D., Radiology Dept., State Univ. of New York, Stony Brook, NY 11794-8460

30. H. J. Biersack, M.D., Director, Klinik fuer Nuklear Medizin, Der Universitaet Bonn, Sigmund Freud Strasse 25, 53127, Bonn 1, Germany

31. A. Bockisch, Ph.D., M.D., Klinik und Poliklinik fuer Nuklearmedizin, Postfach 3960 , Langenbeckstrasse 1, 55101 Mainz, Germany

32. C. Brihaye, Centre de Recherches du Cyclotron, Universite de Liege, Belgium

33. A. B. Brill, M.D., Ph.D., Dept. of Nuclear Medicine, Univ. of Massachusetts Medical Center, 55 Lake Avenue North, Worcester, MA 01655

34. T. F. Budinger, M.D., MS 55/121, Lawrence Berkeley Laboratory, 1 Cyclotron Road, Berkeley, CA 94720

35. A. P. Callahan, Route 1, Box 305 , Harriman, TN 37748

36. J. S. Carty, Isotope Production and Distribution Program, U.S. Department of Energy, NE-46, GTN, Room B-419, Washington, D. C. 20585-1290

37. D. Cole, Medical Applications and Biophysical Research Division, ER-73, Department of Energy, GTN, Washington, D.C. 20585-1290

38. B. Coursey, National Institute for Standards and Technology, Building 245, RM C214 Gaithersburg, MD 20899 
39. J. G. Davis, M.D., Medical and Health Sciences Division, ORAU, Oak Ridge, TN 37831

40. R. F. Dannals, Division of Nuclear Medicine, Johns Hopkins Medical Institutions, Baltimore, MD 21205-2179

41. S.J. DeNardo, M.D., University of California, Davis Medical Center, $4301-X$ Street, FOCB II-E Sacramento, CA, 95817

42. R. Dudczak, M.D., Dept. Nuclear Medicine, I. Medizinische Universitatsklinik, A-1090 Wien, Lazarettgasse 14, Vienna, Austria

43. G. Ehrhardt, Missouri University Research Reactor, University of Missouri, Research Park, Columbia, MO 65211

44. D. R. Elmaleh, Physics Research Dept., Massachusetts General Hospital, Boston, MA 02114

45. L. Feinendegen, Medical Department, Brookhaven National Laboratory, Upton, NY 11973

46. J. Fowler, Chemistry Department, Brookhaven National Laboratory, Upton, NY 11973

47. A. Fritzberg, NeoRx Corporation, 410 West Harrison, Seattle, WA 98119

48. D. M. Goldenberg, M.D., Center of Molecular Medicine and Immunology, 1 Bruce Street, Newark, NJ 07103

49. G. Goldstein, DOE-OHER, Washington, DC 20585

50. G. Griffiths, Immunomedics, Inc., 300 American Rd, Morris Plains, NJ 07950

51. J. Hiltunen, Managing Director, MAP Medical Technologies, Inc., Elementtitie 27, SF-41160 Tikkakoski, Finland

52. Bor-Tsung Hsieh, Ph.D., Institute of Nuclear Energy Research, (INER) Lung-Tan, Taiwan, Republic of China

53. K. Hubner, M.D., Department of Radiology, UT Memorial Hospital, Knoxville, TN 37920

54. J. M. R. Hutchinson,Ph.D., U. S. Dept. of Commerce, National Institute of Standards and Technology, Gaithersburg, MD 20899-0001

55. B. Johannsen, Ph.D., Forschungszentrum Rossendorf e.V.Postfach 5101 19, D-01314 Dresden, Federal Republic of Germany.

56. A. Jones, HMS Radiology Dept., Shields Warren Radiation Laboratory, 50 Binney Street, Boston, MA 02115

57. G. W. Kabalka, Chemistry Department, University of Tennessee, Knoxville, TN 37996-1600

58. G. Kirsch, Department of Chemistry, Universite de Metz, Metz, France

59. J. Kropp, M.D., Klinik fur Nuklearmedizin, der Medizinischen Akademie, Fetscher - Str. 74, 01307 Dresden, Germany

60. D. E. Kuhl, M.D., Division of Nuclear Medicine, University of Michigan Hospitals, University Hospital BIG 412/0028, 1500 E. Medical Center Drive, Ann Arbor, MI 48109-0028

61. R. Lambrecht, Ph.D. Pet-Zentrum des Universitaetsklinikum, Eberhard-Karls-Universitaet Tuebingen, 15 Roentgenweg, Tuebingen 72076, Germany

62. S. Larson, M.D., Sloan-Kettering Inst. for Cancer Research, New York, NY 10021

63. E. C. Lisic,Ph.D., Department of Chemistry, Tennessee Technological University, Cookeville, Tennessee 38505

64. J. Lister-James, Ph.D., Director, Research Administration, Diatech, Inc., 9 Delta Drive, Londonderry, New Hampshire 03053

65. O. Lowe, Isotope Production and Distribution Program, U.S. Department of Energy, NE-46, GTN, Room B-419, Washington, D. C. 20585-1290

66. G. Limouris, Nuclear Medicine Department, Areteion University Hospital, Athens Medical School, Athens, Greece 
67. D. J. Maddalena, FRACl, Department of Pharmacology, Sydney University, NSW 2006, Sydney, Australia

68. John Maddox, 4608 Flower Valley Drive, Rockville, MD 20853-1733.

69. H.-J. Machulla, Eberhard-Karls-Universität Tübingen, Radiologische Universitätsklinik, PetZentrum, Röntgenweg 11, 7400 Tübingen, Germany

70. Frederick J. Manning, National Academy of Sciences, Institute of Medicine, 2101 Constitution Ave., M.W., Washington, D.C. 20418

71. M. Meyer, M.D., Biomedical Research Foundation, P.O. Box 38050, Shreveport, LA 711338050

72. Office of Assistant Manager for Energy Research and Development DOE-ORO, Oak Ridge, TN 37831

73. G. Notohamiprodjo, M.D., Ph.D., Institute of Nuclear Medicine, Heart Center North RhineWestphalia, Bad Oeynhansen, D-4970, Germany

74. C. L. Partain, M.D., Professor and Vice Chairman, Dept. Radiology and Radiological Sciences, Vanderbilt University Medical Center, Nashville, TN 37232

75. R. C. Reba, M.D., Department of Radiology, 5841 S. Maryland Ave., MC 2026, Chicago, IL 60637

76. S. N. Reske, M.D., Klinik für Nuklearmedizin, Arztlicher Direktor der Nuklearmedizin, Klinikum der Universität Ulm Oberer Eselsberg, D-7900, Ulm, Germany

77. M. P. Sandler, M.D., Chief, Nuclear Medicine Section, Vanderbilt University Medical Center, Nashville, TN 37232

78. R. E. Schenter, HO-37, Westington Hanford Co., P.O. Box 1970, Richland, WA 99352

79. A. Serafini, Nuclear Medicine Division (D-57), University of Miami School of Medicine, P. O. Box 016960, Miami, FL 33101

80. S. K. Shukla, Prof., Servizio Di Medicina Nucleare, Ospedale S. Eugenio, Pizzale Umanesimo, 10, Rome, Italy

81. S. Smith, Biomedicine \& Health Program, Australian Nuclear Sci. \& Tech. Org., Lucas Heights Research Laboratories, Private Mail Bag 1, Menai NSW 2234, Australia

82. J. Smith, Ph.D., Research \& Development, DuPont Merck Pharmaceutical Company, 331 Treble Cove Rd., North Billerica, MA 01862

83. A. Solomon, M.D., UT MRCH, 1924 Alcoa Highway, Knoxville, TN 37920-6999

84. P. Som, DVM, Medical Department, BNL, Upton, NY 11973

85. P. C. Srivastava, DOE-OHER, Washington, DC 20585

86. S. C. Srivastava, Bldg. 801, Medical Dept., BNL, Upton, NY 11973

87. G. Strathearn, Isotope Products Laboratories, Inc., 3017 N. San Fernando Blvd., Burbank, CA, 91504.

88-90. Office of Scientific ảnd Technical Information, DOE, Oak Ridge, TN 37831

91. E. A. van Royen, M.D., Ph.D., Head, Department of Nuclear Medicine, Academic Medical Center, University of Amsterdam, Meibergdreef 9, 1105 AZ Amsterdam ZO, The Netherlands.

92. F. C. Visser, M.D., Cardiology Dept., Free University Hospital, De Boelelaan 117, Amsterdam, The Netherlands

93. H. N. Wagner, Jr., M.D., Div. of Nuclear Medicine, Johns Hopkins Medical Institutions, 615 N. Wolfe Street, Baltimore, MD 21205-2179 
94. R. Wolfangel, Mallinckrodt, Inc., 675 McDonnell Blvd., P.O. Box 5840, St. Louis, MO 63134

95. J.-I. Wu, Ph.D., Senior Research Representative, Nihon Medi-Physics Co., Ltd., 2200 Powell Street, Suite 765, Emeryville, CA 94608.

96. S. Wynchank, Research Institute for Medical Biophysics (RIMB), Republic of South Africa

97. Y. Yonekura, M.D., Fukui Medical School, 23 Shimoaizuki, Matsuoka, Fukui 910-11, Japan. 